TECHNO

Vol.20, No.1, April 2019, Hal. 01 09

\title{
METODE LOOK-UP TABLE PADA TAMPILAN JADWAL WAKTU SHOLAT DIGITAL
}

\author{
Anton Yudhana ${ }^{1}$, Abdul Fadlil ${ }^{2}$, Safiq Rosad $^{3}$ \\ ${ }^{1}$ Program Studi Teknik Elektro, Universitas Ahmad Dahlan Yogyakarta \\ 2,3 Program Studi Magister Teknik Informatika, Universitas Ahmad Dahlan Yogyakarta
}

\section{Informasi Makalah}

Dikirim, 25 Oktober 2018

Diterima, 30 April 2019

\section{Kata Kunci:}

Jadwal Sholat Digital

Look-Up Table

Mikrokontroller

\begin{abstract}
INTISARI
Penampil waktu yang menandakan informasi masuknya waktu sholat sering dijumpai di tempat-tempat peribadatan Umat Islam, sebagian besar masjidmasjid saat ini sudah memakai jadwal sholat digital. Namun sering ditemukan waktu sholat yang tertampil tidaklah diperuntukkan untuk daerah tersebut, sehingga kadang mempunyai selisih waktu yang cukup jauh dengan awal waktu sholat sesungguhnya, Hal ini dimungkinkan perbedaan metode dalam menentukan waktu sholat. Dalam penelitian ini, dibuat perangkat yang dapat menampilkan jadwal waktu sholat secara elektronik dengan metode Look-Up Table, metode ini lebih banyak mempunyai alternatif nilai yang didapat dengan menggantikan proses waktu perhitungan dengan operasi pengindeksan array yang lebih sederhana. Perangkat keras dibangun berbasis mikrokontroller AT89S52 dengan penanaman nilai jadwal sholat ke EEPROM dan menentukan tata letak alamat memori dari setiap data waktu sholat yang akan dimasukkan. Tampilan LED yang tersusun menjadi 7segment berupa penanda waktu Jam, Menit, Tanggal, Bulan dan Tahun dengan sumber data waktu berasal dari RTC. Sedangkan sumber data waktu sholat Shubuh, Syuruq, Dzuhur, Ashar, Maghrib dan Isya' berasal dari tabel data waktu sholat pada EEPROM. Hasil yang didapatkan adalah kecepatan dalam mendapatkan data waktu sholat dan keakuratan yang sesuai dengan sumber data jadwal sholat yang digunakan.
\end{abstract}

\begin{abstract}
Time viewers which indicates the initial information on the time of prayer is often found in places of worship of Muslims, nowadays in mosques almost all use digital prayer schedules. However, it is often found that the prayer times that are displayed are not intended for the area, so that sometimes they have a considerable time gap with the beginning of the actual prayer time. This is possible for different methods of determining prayer times. In this study, a device that can display the electronic prayer time schedule using the LookUp Table method is made, this method has more alternative values obtained by replacing the calculation time process with a simpler array indexing operation. The hardware is built on the AT89S52 microcontroller by planting the prayer schedule value into EEPROM and specifying the memory address layout of each prayer time data to be inserted. LED display arranged into 7segment in the form of time clock, Minute, Date, Month and Year with time data source comes from RTC. While the data sources of prayer time Shubuh, Syuruq, Dzuhur, Ashar, Maghrib and Isya 'derived from the table of prayer time data on EEPROM. The results obtained are the speed in getting the data time of prayer and the accuracy of the schedule of prayers in accordance with the agreement on the data source of the prayer schedule used.
\end{abstract}

\section{Korespondensi Penulis:}

Safiq Rosad

Program Studi Magister Teknik Informatika

Universitas Ahmad Dahlan Yogyakarta

Jl. Prof. DR. Soepomo Sh, Umbulharjo, Yogyakarta

Email: rhosyad@yahoo.com 


\section{PENDAHULUAN}

Penunjuk waktu sholat sering ditemui di tempat-tempat peribadatan, baik Masjid maupun musholla, bahkan tidak sedikit juga ditemukan dirumah-rumah pribadi sebagai penanda awal masuknya waktu sholat. Pada Perhitungan (hisab) awal waktu sholat, masing-masing daerah mempunyai kebijakan dalam mengambil metode penentuan awal waktu sholat [1]. Jadwal sholat yang baik merupakan jadwal sholat yang disesuaikan dengan daerah masing-masing dan bukan jadwal dengan hasil koreksian daerah yang dihitung berdasarkan daerah yang berjauhan. Yaitu dengan menambahkan atau mengurangkan waktu jadwal sholat dalam ukuran menit. Hal ini akan menjadi tidak akurat, karena hanya mengambil perhitungan dalam koordinat satu tempat saja. Penentuan yang menjadi persoalan yang klasik adalah dalam penentuan jadwal waktu sholat, karena waktu sholat merupakan masalah ibadah, hal ini menjadi sorotan bagi para ulama dalam dunia ilmu falak.

Beberapa kutipan pendapat penelitian yang telah dilakukan mengenai jadwal waktu sholat dapat susun sebagai berikut:

1. Pendapat dari Jayusman [2], menyebutkan bahwa jadwal waktu sholat selayaknya dikeluarkan oleh pihak yang berwenang. Ahli Falak dan pemegang kebijakan keagamaan atau pihak yang berwenang untuk mengeluarkan jadwal waktu sholat.

2. Dengan melebihkan dan mengurangi jadwal waktu sholat yang ada, merupakan dasar dari sifat kehatihatian dari setiap pengurus masjid, hal ini dikemukakan oleh H. Fanani, Tolha [1].

3. Dalam Membuat kesepakatan jadwal waktu shalat, dipengaruhi oleh beberapa faktor menurut Dharajat [3]. yaitu pertama adalah pengaruh subyektivitas pengurus takmir masjid, Kedua, jadwal waktu shalat yang dijadikan pedoman ada yang menggunakan jadwal waktu shalat harian, bulanan selama satu tahun, ada yang sepanjang masa. Ketiga, terbatasnya ahli ilmu falak yang membuatkan jadwal waktu shalat [3].

4. Perbedaan jadwal waktu sholat sangat dipengaruhi oleh data ketinggian tempat, data kecemerlangan langit, data astronomis, lintang tempat dan nilai ikhtiyat [4].

Dari hasil kajian penelitian sebelumnya, dan diperkuat dengan hasil observasi dalam penelitian ini, sering ditemukan perbedaan dalam penentuan waktu sholat yang akan digunakan. Perbedaan metode perhitungan yang digunakan dalam menentukan waktu sholat akan berdampak pula pada ketidak samaan hasil yang diperoleh. Dilain itu, jadwal sholat juga selayaknya dikeluarkan oleh pihak yang berwenang, dalam hal ini para ahli ilmu falak ataupun pemegang kebijakan keagamaan.

Permasalahan yang diuraikan diatas dapat diambil kesimpulan bahwa dengan adanya perbedaan penentuan waktu sholat. Maka, dalam penerapan sistem penampil jadwal waktu sholat digital tidak bisa secara langsung menggunakan salah satu metode perhitungan yang digunakan. sehingga pada penelitian ini metode yang digunakan adalah mengambil jadwal sholat yang telah di tentukan tanpa melakukan perhitungan. Kemudian data tersebut ditanamkan secara permanen kedalam sistem perangkat keras pada Jadwal Waktu Sholat Digital.

Pada penelitian ini, jadwal sholat yang akan digunakan tidak melakukan perhitungan hisab penentuan awal waktu sholat, akan tetapi jadwal sholat yang digunakan diambil dari badan hisab Kementerian Agama Republik Indonesia (KEMENAG). Jadi metode tampilan yang digunakan adalah metode lookup table, yaitu membandingkan nilai waktu (bulan dan tanggal) dengan jadwal yang tersimpan pada EEPROM. Jadwal Sholat yang dikeluarkan oleh Kementerian Agama Republik Indonesia (https://simbi.kemenag.go.id) dipilih sebagai acuan, karena instansi tersebut adalah badan yang resmi dibentuk oleh pemerintah. Sehingga jadwal sholat yang digunakan juga banyak digunakan oleh masyarakat [5].

\section{METODOLOGI PENELITIAN}

Look-up table merupakan Array (sekumpulan nilai-nilai data yang mempunyai tipe yang sama dalam urutan tertentu yang menggunakan sebuah nama sama) yang dapat menggantikan suatu proses perhitungan dengan operasi pengindek-kan array yang lebih sederhana [6].

Perbandingan dalam proses perhitungan dengan proses look-up table mempunyai perbedaan dalam hal kecepatan dan penghematan waktu, keduanya mempunyai perbedaan yang signifikan, karena mengambil nilai dari memori sering kali lebih cepat dari pada melakukan operasi input/output, perhitungan dilakukan dalam pemrograman atau sebagai bagian dari fase inisialisasi program atau ditanamkan dalam perangkat keras [7]. look-up table juga digunakan untuk memvalidasi nilai input dengan mencocokkan daftar item yang valid (atau tidak valid) dalam sebuah array, dalam bahasa pemrograman mungkin termasuk fungsi pointer untuk memproses input yang cocok .

Untuk membuat fungsi $L O O K-U P$ minimal harus mempunyai 2 tabel :

a. Tabel Utama : berisi data yang akan diproses

b. Tabel Referensi : berisi syarat dan nilai jika syarat itu terpenuhi 
Fungsi $L O O K$-UP mempunyai 2 jenis :

A. $\quad V-L U T$

Digunakan untuk mencari suatu nilai, dari suatu tabel pencarian pada baris yang telah ditentukan dengan metode pencarian menurun atau vertical.

B. $H-L U T$

Digunakan untuk mencari suatu nilai,dari suatu tabel pencarian pada baris yang telah ditentukan dengan metode pencarian mendatar (horizontal).

Ilustrasi Look-Up Table terlihat pada Gambar.1 yang menunjukkan fungsi pada masing-masing V-LUT dan H-LUT. V-LUT merupakan Vertikal Look-Up Table untuk pencarian nilai sesuai dengan nilai referensi yang diberikan, sedangkan H-LUT merupakan Horisontal Look-Up Table sebagai awal penentuan tata letak pencarian V-LUT akan dimulai.

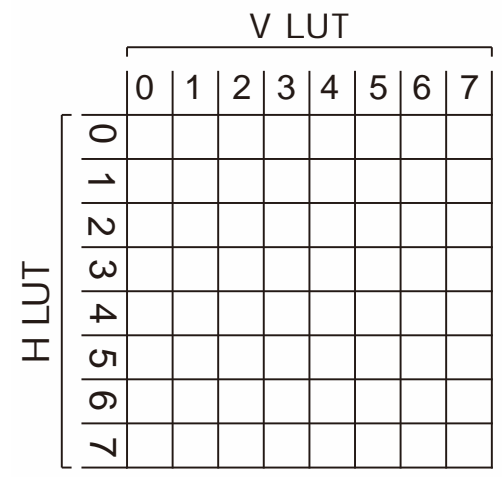

Gambar 1. Look-Up Table Pada Pencarian V-LUT dan H-LUT

Penerapan V-LUT dan V-LUT pada sistem jadwal sholat digital ini adalah penggunaan nilai jadwal sholat yang akan diletakkan/ditanamkan pada perangkat keras EEPROM. Dalam hal ini penentuan peletakkan lokasi alamat memori yang akan letakkan, baik dari awal sampai akhir dari data jadwal sholat keseluruhan dengan menyusun secara berurutan (Array). Dengan mengetahui letak data pada alamat memori dan tersusun berurutan, maka untuk menghasilkan sebuah nilai data diperlukan sebuah nilai referensi alamat memori dan nilai referensi kolom [8].

Nilai data jadwal sholat diletakkan pada masing-masing alamat memori yang telah ditentukan. Gambar.2 merupakan contoh jadwal sholat yang terdiri dari nilai jam dan nilai menit, nilai jam imsyak diambil pada tanggal 1 bulan 1 diletakkan pada alamat $\$ 0000$, kemudian diteruskan dengan nilai imsyak pada tanggal seterusnya (tanggal 2) diletakkan pada alamat memori \$0001.

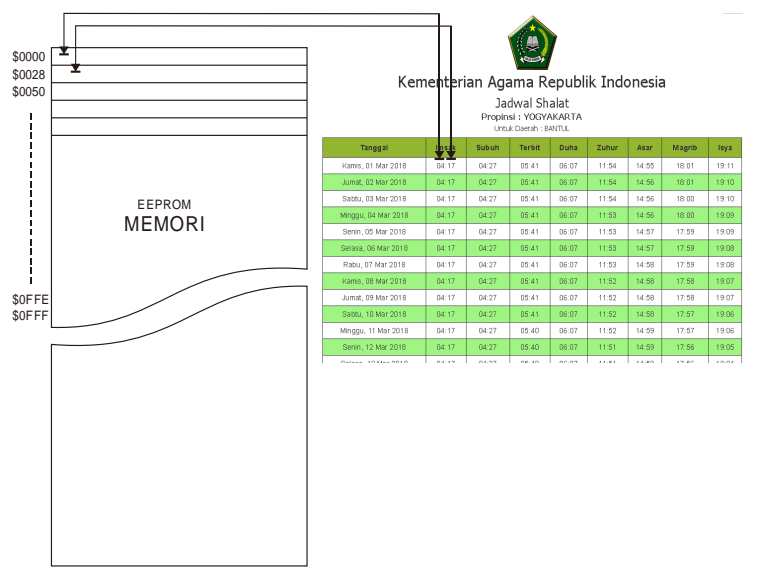

Gambar 2. Peletakan Data Jadwal Sholat Pada Memori Eeprom

Langkah diatas diteruskan sampai pada tanggal 31 atau selama satu bulan penuh, sehingga alamat memori yang diperlukan untuk menyimpan data jam pada waktu imsyak dimulai dari \$0000 sampai \$001F. Setelah peletakkan nilai jam imsyak, dilanjutkan dengan peletakkan nilai menit imsyak, nilai menit imsyak dimasukkan pada alamat memori \$0028 sampai alamat \$0050. Dengan peletakkan nilai seperti cara pada 
Gambar 3, untuk mendapatkan sebuah nilai data waktu sholat diperlukan sebuah nilai referensi alamat dimana setiap bulanya data tersebut diletakkan. Setelah nilai referensi awal alamat dimulai, maka selanjutnya dibutuhkan nilai referensi dari alamat selanjutnya.

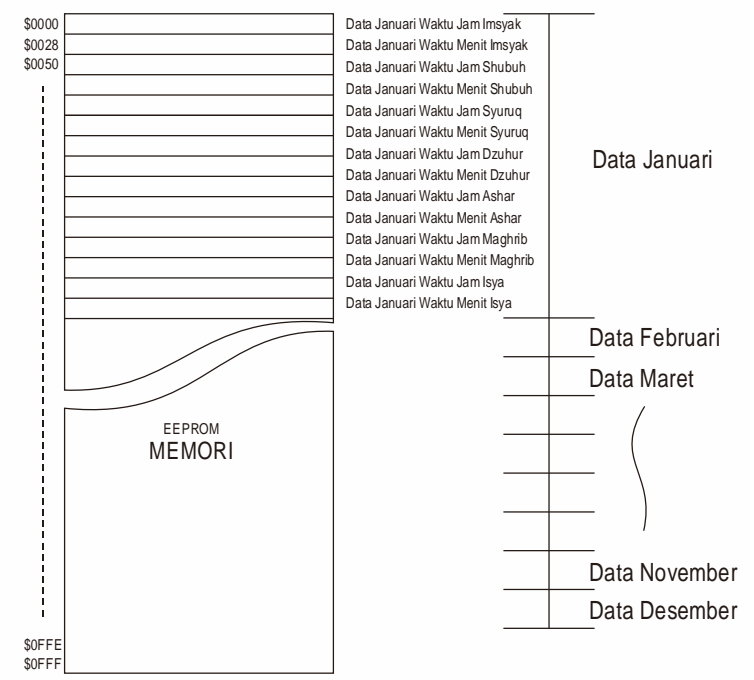

Gambar 3. Peta Memori Dan Peletakkan Data Jadwal Waktu Sholat

Nilai referensi untuk alamat memori awal disebut H-LUT atau dalam data jadwal waktu sholat adalah nilai Bulan, dan nilai referensi alamat selanjutnya adalah V-LUT atau nilai dari tanggal. Nilai data Jadwal sholat akan didapat dan dipengaruhi pada tanggal dan bulan.

\subsection{Perancangan Sistem}

Pada perancangan perangkat keras, akan dibahas mengenai rangkaian elektronik beserta modul komponen-komponen pendukungnya, sehingga alat dapat berfungsi seperti yang diharapkan[9]. Perangkat keras terdiri dari mikrokontroller, Real Time Clock DS3231, EEPROM AT24C64, Buzzer dan 7-segment sebagai penampil dari jadwal waktu sholat. Berikut Gambar.4 diagram Blok perangkat keras yang digunakan.

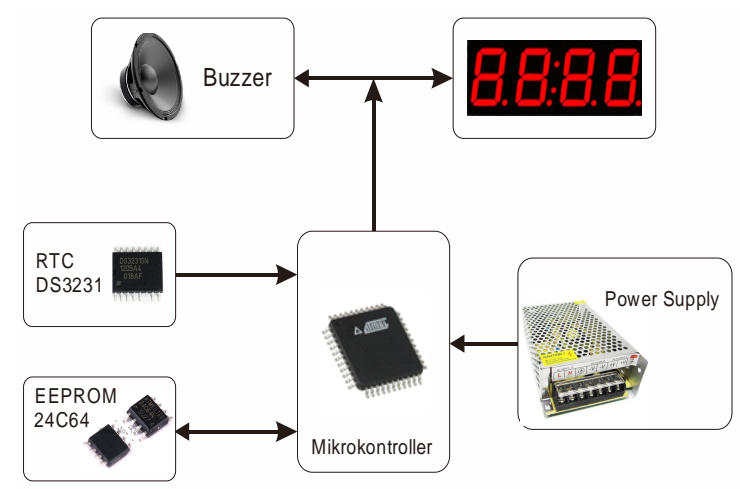

Gambar 4. Diagram Blok Rangkaian Elektronik Jadwal Sholat Digital

Dari diagram blok rangkaian keseluruhan perangkat keras pada Jadwal Sholat Digital diatas, dapat dijelaskan secara terperinci sebagai berikut :

A. Mikrokontroller digunakan untuk mengatur jalanya sistem [10]. Sistem kerja mikrokontroller ini akan mengatur tampilan pada 7-segment, keaktifan Alaram buzzer, pengambilan data dari RTC, membaca dan menulis pada EEPROM. Untuk beroperasi mikrokontroler AT89S52 memerlukan sinyal clock yang dibangkitkan dari oscilator internal dengan menggunakan kristal sebesar $12 \mathrm{MHz}$ dan dua buah kapasitor 30 pf [11]. 
B. Real Time Clock DS3231. RTC - Sebagai Integrated Circuit ( IC ) Penghitung waktu seperti JAM, MENIT, DETIK, HARI, TANGGAL, BULAN dan TAHUN dengan rangkaian yang terdapat baterai backup didalamnya sehingga perhitungan waktu akan tetap berjalan meskipun terjadi pemutusan sumber daya listrik pada rangkaian. Jenis RTC yang digunakan adalah DS3231 dimana dalam pengaksesan komunikasi data antar RTC dengan mikrokontroller menggunakan protokol I2C yang hanya memerlukan 2 jalur atau dua pengkabelan saja.

C. EEPROM

EEPROM ini menggunakan AT24C64, daya tamping sebesar $64 \mathrm{~Kb}$ yang digunakan pada beberapa keperluan, diantaranya adalah :

- $5 \%$ untuk penyimpanan variabel setting jadwal sholat (setting iqomah, penambahan/pengurangan jadwal dan beberapa setting tampilan)

- $\quad 75 \%$ untuk penyimpanan data jadwal waktu sholat (Jam, Menit dan tanggal waktu sholat)

- $20 \%$ sebagai ruang penyimpanan serbaguna, ruang memori yang tidak atau belum digunakan.

EEPROM terhubung menjadi satu jalur dengan komunikasi standar I2C [5]. Dengan protokol I2C, jalur persambungan hanya memerlukan 2 jalur untuk dapat berkomunikasi antara mikrokontroller AT89S52 dengan EEPROM sekaligus dengan RTC, sehingga gambar rangkaian persambungan dengan mikrokontroller dapat disederhanakan pada Gambar 5. Jalur data RTC dan EEPROM tersambung menjadi satu yaitu jalur SDA pada RTC dihubungkan SDA EEPROM dan jalur SCA RTC dihubungkan SCA EEPROM dan menuju ke mikrokontroller denga protokol I2C.

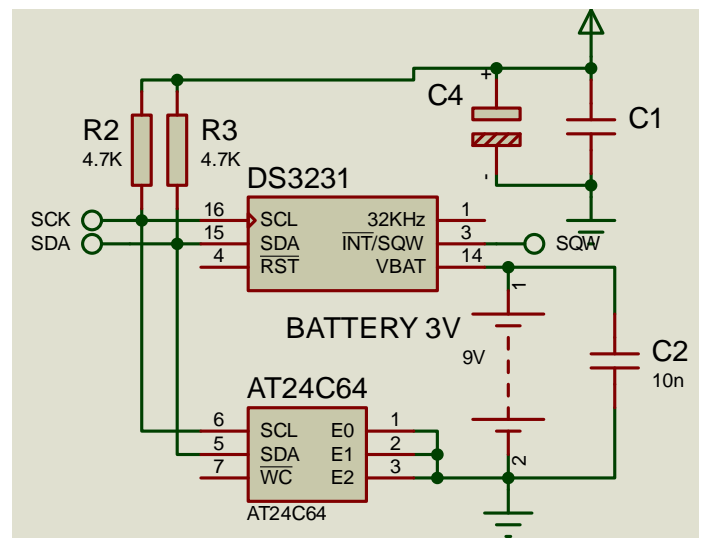

Gambar 5. RTC dan EEPROM Terhubung dengan Mikrokontroller

D. Buzzer digunakan untuk memberi isyarat atau bunyi bep yang terpicu oleh alaram dari tanda waktu awal sholat telah tiba dan sebagai tanda selesainya perhitungan mundur pada jeda Iqomah antara adzan dengan sholat berjamaah.

E. Dalam Jadwal Sholat Digital diperlukan beberapa penampil 7-segment [12]. 7-segment berfungsi agar bisa menampilkan sebuah nilai Jam, Menit, Tanggal, Bulan dan Tahun. Ditambah penampil Jam serta menit 5 waktu Jadwal sholat ditambah jam menit waktu syuruq sehingga jumlah kebutuhan segment adalah :

- $\quad$ Tampilan Waktu $=4$ digit

- $\quad$ Tampilan Kalender $=8$ digit

- $\quad$ Tampilan jadwal sholat 6 waktu $\times 4$ digit $=24$ digit

Perancangan sistem perangkat keras diatas merupakan rangkaian elektronika yang berbasis mikrokontroller [13], dan mikrokontroller yang digunakan adalah AT89S52 [14], jadi rangkaian tidak dapat bekerja seperti yang diharapkan apabila tidak ada perintah-perintah atau pemrograman yang dimasukkan kedalam mikrokontroller[15].

\subsection{Perangkat Lunak}

Sistem dibangun untuk pertama kali akan mengkondisikan dari elemen modul komponen pendukung elektronika seperti Real Time Clock (RTC) dan EEPROM. Kemudian mengambil data waktu yang berasal dari RTC, paket data waktu ini berupa Jam, Menit, Detik, Hari, Tanggal, Bulan dan Tahun. Ilustrasi dalam mengkondisikan status dan pengambilan data RTC dan EEPROM seperti diilustrasikan pada Gambar 6. 


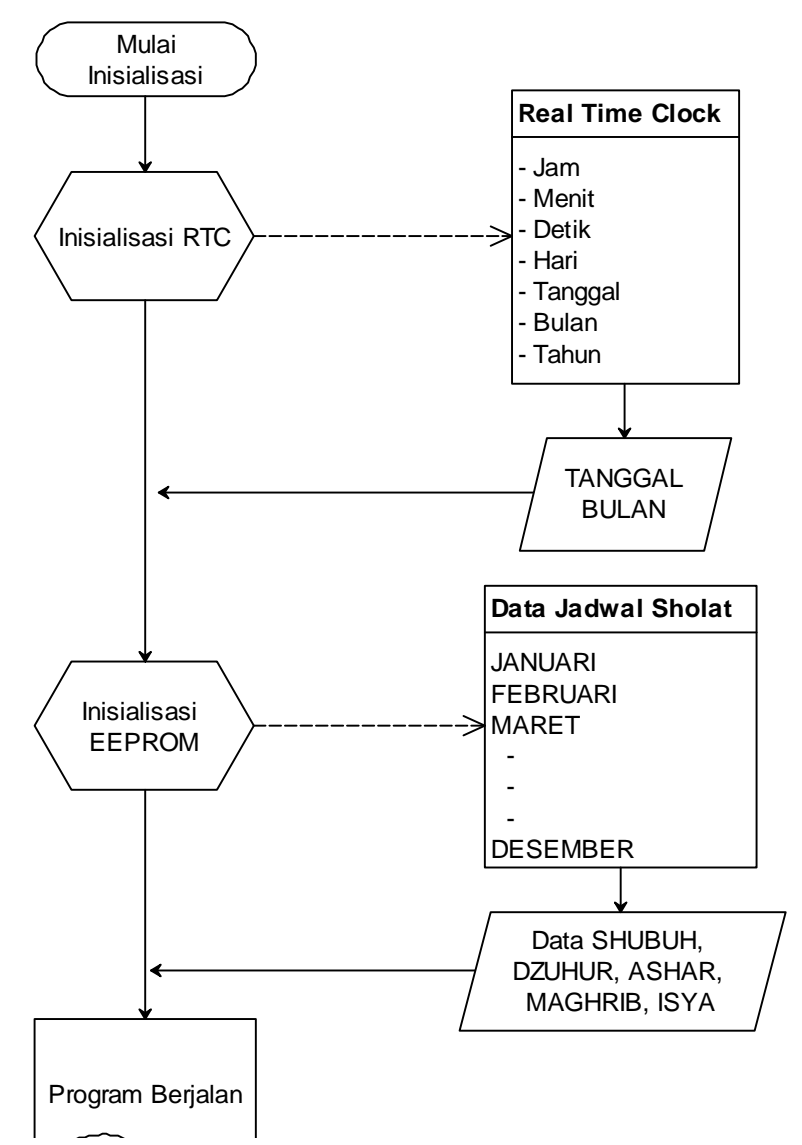

Gambar 6. Inisialisasi Untuk Mendapatkan Nilai Waktu dan Nilai Jadwal Sholat

Dari sini telah didapat data waktu, akan tetapi hanya akan diambil data waktu Tanggal dan bulan sebagai nilai referensi dalam pencarian (Look-Up Table) data waktu sholat yang tersimpan pada EEPROM. Data Waktu Bulan akan digunakan terlebih dahulu untuk mendapatkan nilai referensi H-LUT atau referensi Horisontal, dengan nilai bulan sebagai referensi horisontal akan ditunjukkan pada alamat awal memori tersimpan sesuai dengan data bulan pada masing-masing alamat memori.

Pada Gambar 7, dapat dilihat bahwa, apabila data waktu sholat yang akan dicari adalah bulan januari, maka penunjuk alamat memori akan mengarahkan pada awal data yang diletakkan pada \$0100. Apabila yang dicari bulan agustus maka penunjuk alamat memori akan mengarahkan ke alamat $\$ 2795$, begitu juga pada pencarian penunjuk alamat memori pada bulan yang lainnya.

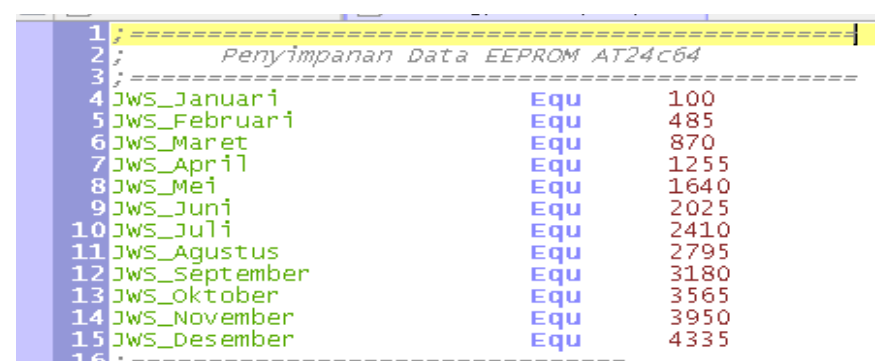

Gambar 7. Penunjukan Nilai Referensi Pada Alamat Memori

Dari sini sudah didapatkan posisi alamat memori yang akan ditunjuk. Selanjutnya adalah diperlukanya nilai referensi sebagai penunjukkan pada V-LUT, yaitu data waktu Tanggal. Waktu tanggal merupakan nilai referensi V-LUT yang akan menunjukkan kolom keberapa dalam array atau urutan data yang sesuai. Dimisalkan data waktu tanggal adalah tanggal 1, maka penunjukkan nilai referensi akan mengarah pada nilai 
05, misalkan nilai tanggal adalah 32, maka akan mengarah pada nilai 00. Dengan cara seperti ini akan didapatkan nilai waktu sholat pada jam.

Untuk nilai waktu sholat pada menit, maka nilai referensi ditambahkan sesuai banyaknya kolom yang dibuat. Disini dibuat kolom berjumlah 32 kolom, maka apabila data waktu tanggal adalah tanggal 1 maka jam bernilai 05 dan menit bernilai 22. Penyusunan tabel data jadwal sholat dapat di lihat pada Gambar 8 .

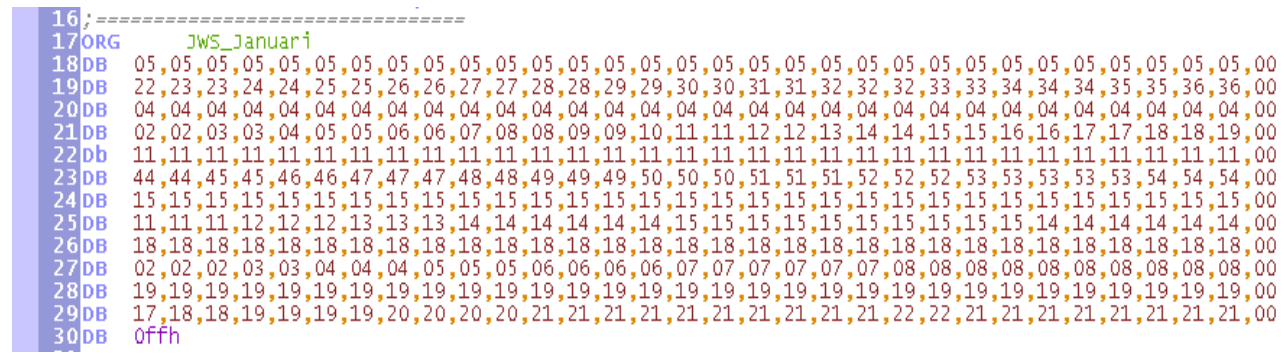

Gambar 8. Tabel Data Jadwal Sholat dalam Pencarian Look-Up Table

Dalam mendapatkan nilai waktu sholat shubuh, dzuhur, ashar dan isya dilakukan sama seperti uraian diatas dengan menambahkan nilai-nilai 32 pada setiap waktu yang telah didapatkan.

\section{HASIL DAN PEMBAHASAN}

Dalam membangun sistem jadwal waktu sholat digital, langkah yang paling terpenting adalah meletakkan atau menanamkan nilai data jadwal waktu sholat ke dalam EEPROM. Ada beberapa langkah yang berurutan dalam pengisian atau penanaman jadwal sholat ke dalam EEPROM[16]:

A. Menyiapkan tabel jadwal sholat yang akan digunakan seperti Gambar 9.

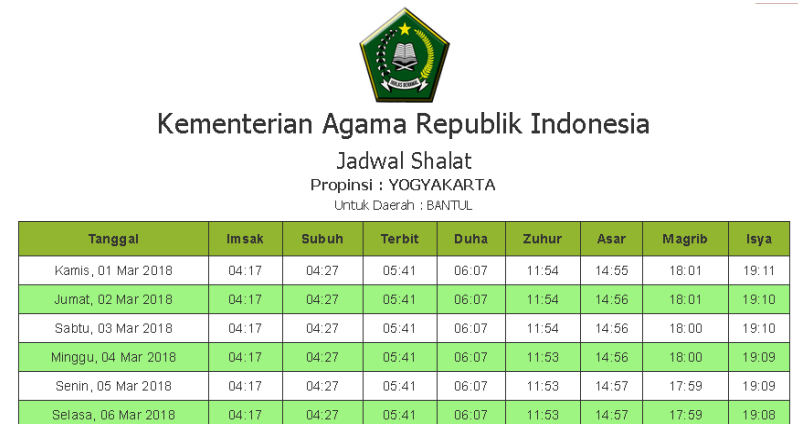

Gambar 9. Data jadwal sholat dari Kementerian Agama

B. Masukkan data pada tabel jadwal sholat ke editor teks. Inisialisasi pada label perintah JWS_Januari, JWS_Februari dan seterusnya adalah penunjukkan nilai referensi (H-LUT) pada alamat memori pada awal data sholat diletakkan atau data pada tanggal ke-satu pada setiap bulanya. Dari Gambar 10, dapat terlihat bahwa susunan tabel merupakan berisi data waktu sholat yang dapat diambil nilainya sesuai dengan data waktu tanggal dan bulan dengan cara pencarian metode Look_Up Table.

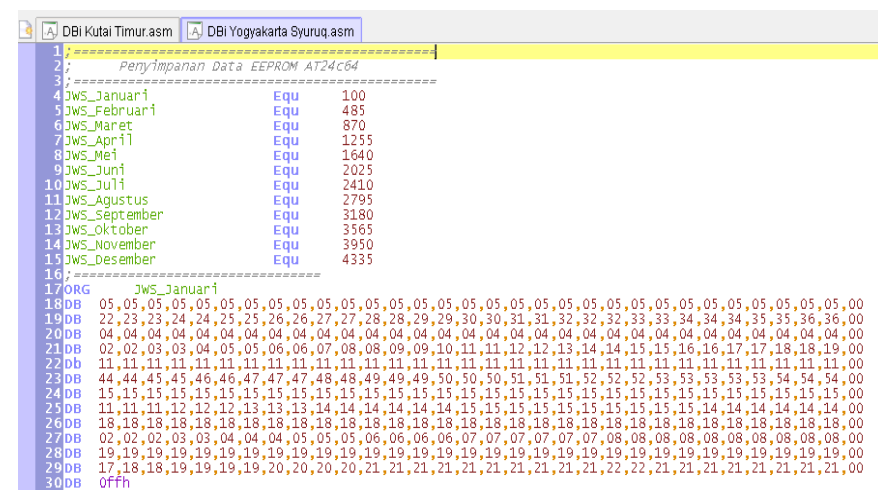

Gambar 10. Nilai Referensi Pada H-LUT 
C. Memasukkan file dari data editor kedalam EEPROM dengan menggunakan alat downloader seperti terlihat pada Gambar 11, atau sering disebut dengan flash EEPROM.

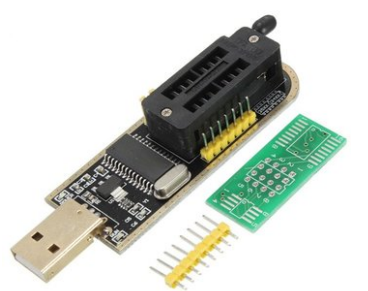

Gambar 11. Alat Flash EEPROM

Langkah diatas merupakan cara pengisian data jadwal sholat ke EEPROM, kemudian EEPROM dapat di terapkan pada perangkat keras (Rangkaian Elektronik) yang akan digunakan. Proses dan langkah dalam pengambilan melalumetode Look-Up Table digambarkan pada diagram alir pada Gambar 12.

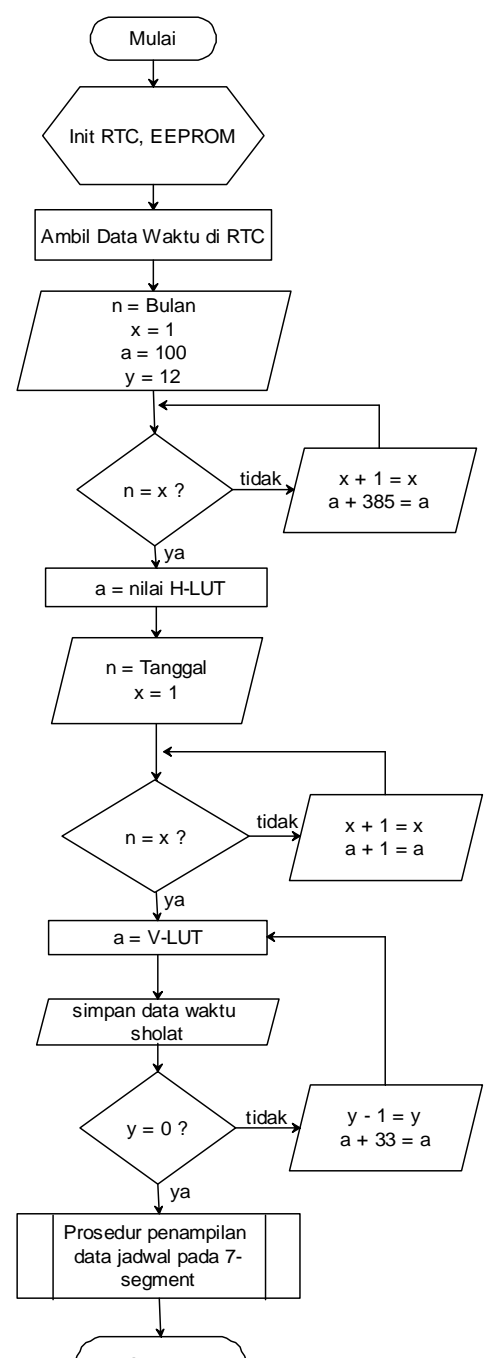

Gambar 12. Diagram alir pengambilan data jadwal sholat

Dalam perangkat lunak yang digunakan, sistem akan bekerja dengan melihat kondisi baik tidaknya pada RTC dan EEPROM. Data waktu jam, menit, hari tanggal, bulan dan tahun akan diambil dari RTC, akan tetapi hanya waktu tanggal dan bulan saja yang akan digunakan sebagai nilai referensi pencarian data jadwal 
sholat pada EEPROM. Dalam pencarian Look-Up Table, nilai referensi yang diperlukan pertama kali adalah H-LUT untuk mendapatkan nilai awal alamat memori, H-LUT diperoleh dari nilai waktu Bulan. Kemudian nilai alamat awal yang telah diperoleh di tambahkan sesuai dari nilai referensi pada V-LUT, yaitu nilai waktu Tanggal.

Dari sini penunjukkan alamat memori telah diperoleh, langkah ini sudah bisa untuk mengambil dari data jadwal sholat yang tersimpan. Namun langkah diatas hanya mendapatkan nilai waktu jam imsyak saja, untuk mendapatkan nilai waktu menit imsyak, shubuh, dzuhur, ashar, maghrib dan isya dengan menambahkan nilai referensi yang terakhir diperoleh dengan variabel 33 ( ref + 33 ). Langkah penambahan tersebut diulang sampai 12 kali dengan didapatkanya nilai menit pada waktu Isya'.

\section{KESIMPULAN}

Hasil kesimpulan yang didapat dari penerapan metode look-Up Table pada tampilan jadwal waktu sholat digital, adalah:

Dalam rekursi yang terjadi ada banyak perhitungan yang berulang kali dikerjakan. Metode dinamic programming termasuk metode Look-Up Table dapat diterapkan dengan menggunakan sebuah array untuk merekam nilai tersebut, Hal Ini akan jauh lebih efisien dan kecepatan dalam mendapatkan data waktu sholat.

Langkah penanaman data jadwal sholat kedalam perangkat keras dan tidak melakukan perhitungan waktu sholat, karena menghindari ketidak akuratan dari jadwal sholat yang digunakan. Perangkat yang dibuat dapat menyesuaikan dengan kebijakan jadwal sholat pada masing-masing masjid.

\section{UCAPAN TERIMAKASIH}

Penelitian ini didedikasikan untuk Magister Teknik Informatika Universitas Ahmad Dahlan, yang telah menyediakan sarana dan prasarana dalam penelitian ini.

\section{DAFTAR PUSTAKA}

[1] H. Fanani, Tolha, "Metode Penentuan Waktu Sholat Di Masjid-Masjid Kabupaten Malang," J. Huk. dan Syariah, vol. 2, no. 2, pp. 135-144, 2011.

[2] Jayusman, "Jadwal waktu salat abadi," J. Khatulistiwa, vol. 3, no. 1, pp. 51-70, 2013.

[3] A. Fadlil, Sunardi, and N. Darajat, Muhammad, "Sistem Informasi Arah Kiblat Dan Jadwal Waktu Shalat Di Kota-Kota Besar Di Indonesia," in Prosiding Interdisciplinary Postgraduate Student Conference 1, 2016, pp. 104-109.

[4] Ismail, "Metode Penentuan Awal Waktu Salat dalam Perspektif Ilmu Falak," J. Ilm. Islam Futur., vol. 14, no. 2, pp. 73-93, 2015.

[5] A. Yudhana, A. Fadlil, and S. Rosad, "Rancang Bangun Jadwal Sholat Digital Terkendali Android," SEMANTIKOM, pp. 25-32, 2017.

[6] W. Hu, F. Chen, and L. Zhang, "Using Lookup Tables to Match Data," SESUG, no. c, pp. 1-7, 2008.

[7] Muchlas, Sunardi, and T. Antoro, "Pengendalian kecepatan motor dc dengan metode look up table berbasis mikrokontroler at89c51," Telkomnika, vol. 4, no. 1, pp. 1-10, 2006.

[8] Turahyo and Noviarianto, "Implementasi Sinusoidal Pulse Width Modulation Pada Inverter Satu Fase Berbasis Lookup Table Menggunakan Mikrokontroler 16-Bit," Semnastek, no. November, pp. $1-2,2017$.

[9] E. Prasetyono, R. W. Wicaksana, and N. A. Windarko, "Pemodelan dan Prediksi Daya Output Photovoltaic Secara Real Time Berbasis Mikrokontroler,” no. 2, pp. 190-199, 2015.

[10] S. Aji, Muchlas, and Sunardi, "Perancangan Pengukur Swr Digital Dan Pengaman Transmiter Fm 88-108 Mhz Berbasis Mikrokontroler At89s51," Telkomnika, vol. 5, no. 3, pp. 207-216, 2007.

[11] T. Sutikno, A. Yudhana, and D. Siprian, "Pengaturan Sakelar Pada Acara Cepat Tepat Berbasis Mikrokontroler At89C2051,” TELKOMNIKA, vol. 4, no. 3, pp. 185-192, 2006.

[12] Sunardi, W. Aji, and R. Firdaus, "Aplikasi Mikrokontroler AT89C51 Pada Model Alat Pembersih Lantai," TELKOMNIKA, vol. 3, no. 3, pp. 151-161, 2005.

[13] S. Yunus and I. Ismail, "Studi Penempatan dan Kapasitas Pembangkit Tersebar terhadap Profil Tegangan dan Rugi Daya," Jur. Tek. Elektro, vol. 7, no. 1, pp. 1-4, 2016.

[14] U. Sutisna and S. Nurhadiyono, "Perancangan Saklar Pemindah Otomatis Pada Instalasi Genset dengan Parameter Transisi Berupa Arus Berbasis Mikrokontroller ATMEGA16," vol. 16, no. 2, pp. 70-78, 2015.

[15] R. Passarella, K. Exaudi, J. S. Komputer, F. I. Komputer, and U. Sriwijaya, "Perancangan Sistem Navigasi Robot Kapal Katamaran untuk Menghindari Rintangan Menggunakan Logika Fuzzy," vol. 7, no. 1, 2018.

[16] Syafii and K. Putri, Ika, "Analisa Operasi Ekonomis Pembangkit Termal untuk Melayani Beban Puncak Sistem Kelistrikan Sumbar,” vol. 7, no. 1, pp. 1-7, 2018. 